\section{Forskningsbasert om juks blant studenter}

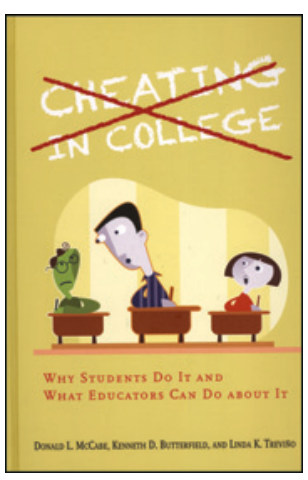

Donald L. McCabe, Kenneth D. Butterfield, Linda K. Treviño

\section{Cheating in college}

Why students do it and what educators can do about it. 225 s, tab. Baltimore, MD: The Johns Hopkins University Press, 2012. Pris USD 40 ISBN 978-1-4214-0716-6

I disse tider med stadige oppslag i mediene om juks og korrupsjon innen næringsliv, forskning, politikk og sport, forbauser det vel ingen at også elever og studenter jukser. Men omfanget kan kanskje komme som en overraskelse. Mer enn to tredeler av collegestudenter i USA svarer at de det siste året har gjort noe som passer i kategorien akademisk uhederlighet (academic dishonesty).

Forfatterne har forsket på juks i høyere utdanning i over 20 år, og boken er basert på deres egne og andres forskningsresultater, overveiende fra USA. De belyser akademisk uhederlighet fra ulike synsvinkler, med kvantitative data i bunnen: prevalens, typer av juks, karakteristika ved studenter som jukser, institusjonelle faktorer, lærernes rolle, og til sist hva som kan gjøres for å bedre forholdene. Det er en stor fordel med en bok som tar utgangspunkt i fakta, og som tar hensyn til disse når hypoteser og meninger fremsettes.

Forfatterne begynner med å spørre om hvorfor man skal bry seg - er det så farlig? Deres klare mening er at fenomenet må tas mye mer alvorlig enn det gjøres i dag, først og fremst fordi dagens studenter er morgendagens ledere og politikere.

Blant forhold som i særlig grad ser ut til å påvirke studentenes atferd, er - ikke overraskende - holdninger og atferd blant medstudenter, lærere og fakultetsledelse. De påpeker at en tilbakeholden, eller kanskje heller likegyldig, holdning er utbredt. Selv om forfatterne ser behovet for tydelige sanksjoner, advarer de mot å tro at fenomenet lar seg bekjempe med en «lov- og orden»-tilnærming. Studentenes atferd vil kanskje endres, ikke fordi de er blitt mer etisk bevisste, men bare som en opportunistisk tilpasning.

Hovedbudskapet er at det først og fremst må satses på en «...etisk samfunnsbyggende tilnærming - hvor studenter kontrollerer sine impulser og holder seg til positive standarder fordi etablering og vedlikehold av et samfunn bygget på tillit betyr mye for dem». Hvis ikke studentene opplever at deres lærere og foresatte selv lever etter høye og tillitsskapende standarder, og forventer det samme av dem, kan man ikke regne med vesentlige endringer. Siste kapittel heter da også Creating a culture of integrity: practical advice for faculty and administrators.

Denne boken har noe viktig å si til alle som deltar direkte eller indirekte i utdanning. Det er nok av synsing, sterke meninger og enkle løsninger når det gjelder juks blant studenter og andre grupper. Forfatterne gir oss både tilgang til kjærkomne fakta om fenomenet, og en grundig analyse og syntese - basert på klare verdivalg.

\section{Best på slutten}

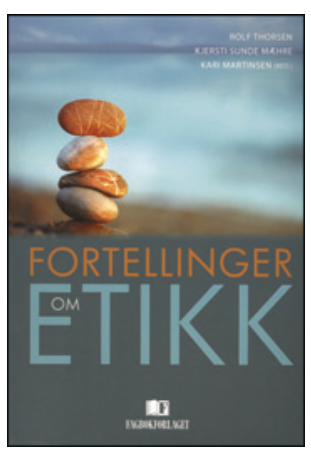

Rolf Thorsen, Kjersti Sunde Mæhre,

Kari Martinsen, red.

Fortellinger om etikk

185 s. Bergen: Fagbokforlaget, 2011.

Pris NOK 355

ISBN 978-82-450-1159-3

Fortellinger om etikk oppgis å vere aktuell for alle som jobbar for og med menneske, både på bachelorutdanning og høgare nivå. Men det meste av boka er skrive ut frå eit sjukepleiarperspektiv, og kan oppleves mest relevant for denne yrkesgruppa.

Boka består av 7 kapittel som kan lesast kvar for seg, og kvart kapittel har ulik forfattar. Dermed blir det noko gjentaking, til dømes med referering og forklaring av Løgstad ( Vi er hinandens verden og skjebne) og Levinas (Ansvar for den Annen) fleire gonger. Det er eit resymé av kvart kapittel i byrjinga. Språket er lett tilgjengeleg, og med stor skrift og relativt få sider er ho fint overkommeleg.

Anmeldaren opplever at boka tek seg gradvis opp. Dei første tre kapitla seier noko om viktigheita av å lytte til kvar pasient si unike fortelling og bruke klinisk skjønn, og ikkje å la seg binde av fastlagte normar og malar i pasientmøta. Men dette er ikkje noko nytt, og det manglar også ei problematisering av å la det gå for langt den vegen. I det fjerde kapittelet reflekterer forfattarane kring det å gi hjelp til døyande, og den smerten hjelpepersonal (sjukepleiar) kan kjenne på i ei intensivavdeling. Eutanasi berøres også. Men det manglar ei formidling av kompleksiteten som omgir desse temaa. I det femte kapittelet er sterke kliniske vignettar om valdsutsette kvinner basis for refleksjonar. Dei to siste kapitla er dei klart beste. Eitt omhandlar krenkingar med søkelys på «blinde og døve pleiekulturar». Det siste belyser skam, også av det gode, som hindrar oss i å gå over grensa til noko som skal få vere framand. Det gir stoff til vidare ettertanke og personleg refleksjon.

Eg anbefaler å lese dei siste kapitla først, og bla vidare framover om du er særskild interessert.

\title{
Jeanette Bjørke-Bertheussen
}

Psykiatrisk divisjon

Stavanger universitetssjukehus 